\title{
Ethylene Dibromide
}

National Cancer Institute

\section{Source}

National Cancer Institute. Ethylene Dibromide. NCI Thesaurus. Code C490.

A clear, colorless, volatile liquid brominated hydrocarbon with a mild, sweet, chloroformlike odor that emits corrosive and toxic fumes when heated to decomposition. Ethylene dibromide is used as a chemical intermediate in the synthesis of resins, waxes, gums, dyes and pharmaceuticals and is used to produce vinyl bromide. Exposure to ethylene dibromide severely irritates the skin and causes depression and collapse. Ethylene dibromide affects DNA integ rity by alkylation and is reasonably anticipated to be a human carcinogen. 